\title{
Digital transformation in sales as an evolving process
}

\author{
Stefan Wengler \\ Hof University, Hof, Germany \\ Gabriele Hildmann \\ KAIROS GmbH, Kronberg, Germany, and \\ Ulrich Vossebein \\ Technische Hochschule Mittelhessen, Friedberg, Germany
}

\begin{abstract}
Purpose - The majority of business-to-business companies are working on their digital transformation in sales. Despite enormous transformation efforts, the expected productivity gains are often missing in most companies. Based on empirical research, this paper aims to develop a new marketoriented transformation model. Management implications as well as future research directions are derived for a more focused digital transformation process in sales.

Design/methodology/approach - Within the exploratory research study, 90 key informants were interviewed to provide better insights in the context of digital transformation in sales. The accuracy of the research results was safeguarded by triangulation.

Findings - As this research paper will show, the reasons for the missing productivity gains caused by a limited knowledge about the main success factors of digital transformation as well as a lack of understanding of digital transformation as an evolving process.

Originality/value - Based on the empirical research, a new market-oriented transformation model is developed and management implications as well as future research directions are derived for a more focused digital transformation process in sales.
\end{abstract}

Keywords Business type, Capacity building, Data, Digital technoligies, Digital transformation, Ecosystem, Key performance indicators (KPI), Market intelligence (MI), Market-oriented transformation model (MTM), People, Process, Sales

Paper type Research paper

\section{Introduction}

A company's digital transformation can lead to substantial productivity gains (Brynjolfsson and Hitt, 1998, 2000): modern information technology (IT) reduces communication and coordination costs significantly and/or allows companies to improve their existing product portfolio or even create new products. Thus:

[...] the business value of computers is limited less by computational capability and more by the ability of managers to invent new processes, procedures and organizational structures that leverage this capability (Brynjolfsson and Hitt, 2000).

Accordingly, most business-to-business companies have started their digital transformation projects to further ensure their competitiveness (Tabrizi et al., 2019).

Sales is making its own effort in contributing to the productivity gains of the company: since the 1980s sales researchers have been particularly concerned with the implementation of digital technologies in the form of customer relationship management (CRM) systems or sales force automation (SFA) (Buttle et al., 2006; Honeycutt, 2002;

The current issue and full text archive of this journal is available on Emerald Insight at: https://www.emerald.com/insight/0885-8624.htm

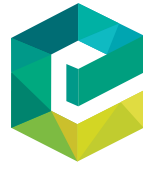

Journal of Business \& Industrial Marketing 36/4 (2021) 599-614

Emerald Publishing Limited [ISSN 0885-8624] [DOI 10.1108/JBIM-03-2020-0124]
Srivastava et al., 1999; Tanner et al., 2005). Since the 2010s, sales research has increasingly included additional digital tools such as social media, mobile marketing (Lamberton and Stephen, 2016; Kumar et al., 2020) and only recently also artificial intelligence (AI) technologies (Singh et al., 2019).

Despite the companies' enormous efforts and investments in their digital transformation, the scientific discussion revolving around the "productivity paradox" (Gordon, 2016; Saniee et al., 2017; Solow, 1987) has never really stopped as the expected productivity gains have hardly materialized (Acemoglu et al., 2014; Buttle et al., 2006) or the transformation projects have even failed (Davenport and Westerman, 2018). Consequently, companies are uncertain about the future direction of their digital transformation process.

This research paper aims to provide a conceptual framework on how to engage more adequately in the digital transformation

(C) Stefan Wengler, Gabriele Hildmann and Ulrich Vossebein. Published by Emerald Publishing Limited. This article is published under the Creative Commons Attribution (CC BY 4.0) licence. Anyone may reproduce, distribute, translate and create derivative works of this article (for both commercial \& non-commercial purposes), subject to full attribution to the original publication and authors. The full terms of this licence may be seen at http://creativecommons.org/licences/by/4.0/legalcode

The authors are gratefull to the two anonymous reviews for their valuable comments and suggestions, which have helped in finalizing the manuscript.

Received 1 March 2020

Revised 31 July 2020

Accepted 11 September 2020 
process in sales by identifying the key management areas of digital transformation as well as by taking interdependencies across the company's departments and the company's ecosystem into account. In the following sections, the paper reviews the literature on digital transformation in sales, explains the design of the exploratory research study, highlights its major findings and derives a market-oriented model for digital transformation. Based on these insights, management implications for companies as well as directions for future research will be derived.

\section{Literature review on the digital transformation in sales}

Despite the impression that the phenomenon of digital transformation must have been exhaustively discussed from a theoretical and practical point of view (Bharadwaj et al., 2013; Hess et al., 2016; Matt et al., 2015; Ross, 2019; Westerman et al., 2011), it still has to be considered as a rather young research domain (Vial, 2019; Singh et al., 2019). Based on a comprehensive research study using grounded theory (Wolfswinkel et al., 2013), Vial (2019) shows in his paper that researchers are still not clear about the definition of "digital transformation," its scale and scope as well as the differences between "digital transformation" and "IT-enabled transformation."

The term "digital transformation" is primarily discussed in the research domain of "Information Systems" (Vial, 2019), but increasingly also in sales (Singh et al., 2019), and encompasses profound organizational (Hess et al., 2016) as well as societal changes (Agarwal et al., 2010; Majchrzak et al., 2016). However, many of the proposed definitions use unclear terms, are circular and conflate the concept and its impact (Vial, 2019). Instead, definitions on "digital transformation" should clearly state the unit of analysis, the transformation's scope, the means of the transformation as well as the expected outcome. Although we principally agree with Vial's approach, his suggested definition of "digital transformation as a process that aims to improve an entity by triggering significant changes to its properties through combinations of information, computing, communication, and connectivity technologies" (Vial, 2019) as a synthesis of his research does not really provide more clarity from a management's perspective.

In contrast to Vial, the unit of analysis should not be an undefined "entity," but the company itself. Marketing and sales are not interested in transformation in general (e.g. across corporations, industries and society), but in a manageable, i.e. influenceable and controllable, transformation process, which can only take place within a company. This does not neglect the companies' ecosystem (Bronfenbrenner, 1979; AarikkaStenroos and Ritala, 2017), whose interdependencies have to be clearly acknowledged; but the ecosystem needs to be considered more as a company's strategic framework rather than a manageable unit. Also, the terms "process" or "triggering significant changes" neither describe the scale and the scope nor the outcome of digital transformation adequately. Reflecting on the impact of digital technologies, changes occur regarding the design of processes (Denner et al., 2018; Picot et al., 2008; Shapiro and Varian, 1999), the development of smart products and services (Chowdhury et al., 2018), the creation of new business models (Loebbecke and Picot, 2015; Ritter and Pedersen, 2020) as well as the working behavior of people (Hirsch-Kreinsen, 2016). All these changes need to be managed in a way that improves a company's competitiveness, i.e. increasing its effectiveness as well as its efficiency (Hunt and Duhan, 2002). We therefore suggest defining the term "digital transformation" as "[...] the modification of processes, products, business models as well as human behaviors by digital technologies, which aims at designing the companies' business activities more efficiently and effectively." Thereby, we consciously leave the term "digital technologies" ambiguous, because the width and breadth of the existing and upcoming digital technologies can hardly be defined from today's point of view (Lamberton and Stephen, 2016; Singh et al., 2019), but they are anyway just means to improve a company's competitiveness.

In addition, the term "digital transformation" captures much better the strategic dimension as well as the value-creation objective of current developments: When researchers discussed the issue of "IT-enabled transformation" in the 1980s and 1990s (Ginzberg, 1981; Hill and Swenson, 1994; Zuboff, 1988), they were primarily focusing on the technological dimensions, rather than on the business or even societal implications of using and implementing information technologies (Bharadwaj et al., 2013). The perspective has changed considerably, as companies increasingly understand the fundamental impact of digital technologies on people' daily life and companies' processes (Shapiro and Varian, 1999; Picot et al., 2008) as well as the relevance of corporate's ecosystems (Aarikka-Stenroos and Ritala, 2017) within the companies' value creation process (Anderson and Narus, 1998; Slater, 1997; Ulaga and Eggert, 2006; Woodruff, 1997). Particularly, the companies' slow shift toward the concept of value creation (Kumar and Reinartz, 2016; Terho et al., 2012; Wirtz and Ehret, 2017) implies their increasing awareness of and requirement for a more sophisticated market intelligence (MI). Even though the required data collection can be perfectly facilitated by the diverse digital technologies (Brynjolfsson and Kahin, 2002; Iansiti and Lakhani, 2014; Tanner et al., 2005), the company's business logic as well as the required processes and data need to be defined before hand (Brynjolfsson and Hitt, 2000; Buttle et al., 2006; Loebbecke and Picot, 2015).

Beyond the challenges of defining "digital transformation," it is still unclear how digital transformation works properly (Matt et al., 2015). Various approaches are suggested [see Vial (2019) for an overview] but are mainly technology driven, even though the customer experience should be the prime focus in the transformation process (Steward et al., 2019; Tabrizi et al., 2019). Already since the 1990 s, but more intensely since the 2000s (Honeycutt, 2002; Speier and Venkatesh, 2002; Srivastava et al., 1999), sales researchers have been concerned with the impact of the internet, new communication technologies as well as CRM systems on selling and sales management. By using CRM systems:

[...] these customer data provide a complete record of the customer's interactions in a timely and readily accessible format to drive the analytic CRM process, the development of marketing strategies, and feedback (or suggestion prompts) to the sales force and channels. As a consequence, the firm is more likely to settle on a "holistic" view of the customer that will enable enterprise-level marketing, sales, and channel decisions that drive customer satisfaction through more timely, relevant, and personalized products/service offers, messages, and interactions (Tanner et al., 2005). 
Despite the great opportunities and further intense research (Lamberton and Stephen, 2016; Obal and Lancioni, 2013; Singh et al., 2019; Steel et al., 2013; Stein et al., 2013), the application of digital technologies never really did meet these huge expectations, neither for CRM systems nor for SFA (Buttle et al., 2006; Cascio et al., 2010; Choa and Chang, 2008; Honeycutt, 2005; Speier and Venkatesh, 2002; Stein et al., 2013). Speier and Venkatesh (2002) identified a mismatch between the design of the implemented tools and salespeople's competencies as the tools did not "play to the strengths" of the salespeople. Buttle et al. (2006) are convinced that the major reason for failures regarding the implementation and application of digital technologies in sales is the companies' current prime focus on "people" and "technology," even though "process" is at least as important as the other two factors (Buttle, 2004; Wright and Donaldson, 2002). During a company's digital transformation, designing or re-engineering its selling processes will be key to enabling its sales organization to fulfill the customers' needs even more efficiently and effectively than before (Brynjolfsson and Hitt, 2000; Loebbecke and Picot, 2015). On top, companies take on a too myopic view as they neglect their customers as well as their business context, especially their partners and/or their competitors, when designing their digital transformation strategies (Buttle et al., 2006).

Regardless of these unsolved issues, more recent research is focusing on the application of "Big Data" (Chierici et al., 2019; Elia et al., 2020; Hajlia et al., 2020; Hallikainen et al., 2020; Wang and Wang, 2020), social media and other digital tools (Ancillai et al., 2019; Lamberton and Stephen, 2016; Nunan et al., 2018; Pascucci et al., 2018; Wang et al., 2017) or even AI (Singh et al., 2019) in business-to-business transactions. Notwithstanding, the increasing amount of literature on digital transformation in sales and research in this domain is highly fragmented and primarily focuses on specific stakeholders of the sales transformation process, which Buttle et al. (2006) already pointed out almost 15 years ago and which is still valid today. The high value of this research in the domain of "sales profession" and "sales professionals" (Singh et al., 2019) is unquestionable, but it will only partly be able to answer why companies' digital transformation projects (in sales) succeed or fail. The sales people and sales organization are interdependent with the rest of the company's departments and the company to think and act fully market oriented (Day, 1994; Narver and Slater, 1990; Slater and Narver, 1995). Thus, it is necessary to widen the research perspective, take the company with all its departments as well as its ecosystem into account and build a model for "digital transformation" on theoretical grounds (Buttle et al., 2006). Only then, can we derive explicit management recommendations for the digital transformation in sales, and thereby include the more specific research on "sales profession" and "sales professionals" again.

With the following exploratory research study, we therefore aim for a more comprehensive approach capturing the complexity and interdependencies of the sales processes, digital (sales) technologies and its ecosystem.

\section{Design of the exploratory research study}

Considering the results of the literature review and Buttle et al.'s (2006) request for a more theoretical approach toward explaining digital transformation in sales, an exploratory research study was initiated to provide more insights in the context of digital transformation in sales. In the following section, the research questions will be developed, then the setup of the research sample and the data collection will be described, and the procedure of the expert interviews will be explained.

\subsection{Development of research questions}

Although companies have already started to transform their businesses using digital technologies to increase their competitiveness (Tabrizi et al., 2019), it is still unclear in the sales research literature who really is or who should be in charge of the whole process and who/what is driving the digital transformation in sales (Matt et al., 2015). The same is true for the barriers to the transformation process as well as the company's know-how of and readiness for the digital transformation in sales (Vial, 2019). The following three questions were therefore derived regarding the perception of the digital transformation process in sales within the companies:

Q1. Who should be responsible for the digital transformation in sales?

Q2. Who/what are the major drivers of digital transformation in sales and who/what are the major barriers?

Q3. Do you think that your company has the necessary know-how to succeed in its effort of digital transformation in sales?

Reviewing the business-to-business sales management literature shows a long history, but also a wide variety of sales management approaches (Anderson et al., 2008; Bohlig and Care, 1975; Cuevas et al., 2015; Guenzi and Geiger, 2011; Ingram et al., 2015; Johnston and Marshall, 2013; Wotruba, 1981). Researchers more or less agree on the sales process consisting basically of the five sales process steps, market analysis, selection of target customers and lead generation, negotiation, business transaction and after sales. But, the concept of business types is rather unknown in business-to-business sales management research (outside of Germany), even though it builds upon a sound theoretical theory, i.e. transaction cost economics (TCE). However, the acknowledgment of business types is key for better explaining as well as understanding the wide variety of sales approaches as there is a fundamental difference if a company sells copy machines, office supplies, power plants or high-tech components for the automobile industry. Already in the late 1970s/early 1980s researchers developed the idea of business types (Backhaus and Guenter, 1976) based on TCE (Williamson, 1975) and since then researchers distinguish the following three business types with respect to their degree of asset specificity (Backhaus and Muehlfeld, 2005), i.e. to which degree the company can only make use of its assets in a specific bilateral transaction context:

- the product business (low asset specificity); 
- the project business (medium asset specificity); and

- the relational business (high asset specificity).

While in the product business companies produce standardized products in advance and wait for orders, which are then primarily served from stock, companies active in the project business and the relational business only start producing their products after the negotiation has successfully been completed, because these products are highly customized. The main difference between the project business and the relational business is that in the project business, it is a onetime project (e.g. building a bridge or a power plant), whereas in the relational business, the customer is served on a regular basis with the same product (e.g. component/ system supplier in the automobile industry). The more customized the company's products are, the more dedicated are its machine park, its human resources etc. to that transaction design - and thus the higher is its asset specificity. As each of these business types requires a different sales approach for safeguarding against opportunistic behavior (Williamson, 1975), the design of the five general sales process steps will change considerably. Consequently, the application of digital sales technologies as well as the design of the digital sales technologies' functions/features will also differ with respect to the chosen business type.

To allow a better comparison between the different business types, we applied in the research study a unified sales process in all three cases, but asked the interviewed persons for an individual evaluation of each sales process step (market analysis, selection of target customers and lead generation, negotiation, business transaction and after sales) within the specific business type. In addition, the maximum digitization potential, the current degree of digitization and the subsequent future digitization potential of each single sales process step was assessed. Based on these considerations, the following four questions were asked for better understanding the differences between business types with respect to the digital transformation in sales:

Q4. In which business type(s) are you active?

Q5. Assess the relevance of each sales process step within your business type (by distributing 100 points across all 5 sales process steps).

Q6. Given all activities within each sales process step, how much can be digitally processed (in percentage)?

Q7. How much of the sales process steps' activities have your company already digitized, which can be digitized at all (in percentage)?

Besides these aspects of individual perception of the transformation process as well as the relevance of the business type, we also asked the interviewees in an open question for additional aspects, which were relevant from their point of view to master the digital transformation in sales on an operational level successfully. The final research question therefore is:

Q8. Which aspect(s) do you think are also essential to master the digital transformation in sales on an operational level successfully?

\subsection{Sample and data collection}

Because of the width and breadth of the topic of "digital transformation in sales," we decided to conduct an exploratory research study based on expert interviews. Therefore, the authors used the methodology of key informant (Churchill, 1979), who is an expert source of information and has more insights into specific topics than others because of its personal skills or position within an organization. Using single key informants for each company, however, would not lead to reliable and valid results as our own pre-study indicated. The individual perspective on the transformation process varies significantly depending on the hierarchical level of the interviewed person. Trying to contain the problem of "informant bias" (Bagozzi et al., 1991), triangulation (Rindfleisch et al., 2008; Van Bruggen et al., 2002) was applied to improve the accuracy of the key informant approach (Homburg et al., 2012). In the exploratory study, which took place from January to November 2017 in Germany, we therefore interviewed 90 persons from 30 German mediumsized companies with an average annual turnover of $€ 250 \mathrm{~m}$ and around 1,300 employees. Each company allowed us to interview three people, one managing director (MD)/member of the board of management, one sales director (SD) and one sales representative. We were thus able to make the results more comparable and meaningful. All interviews were conducted personally or via telephone and took between 90 and $180 \mathrm{~min}$.

The expert interviews were only conducted by senior sales management researchers. Based on a semi-standardized questionnaire, the arguments and assessments of the interviewees were documented in a written form and later analyzed using in-depth text analysis method. The text analysis was conducted by two independent researchers and their results were later compared to ensure correct comprehension. After the analysis, the results were verified by the interviewees in a separate follow-up-meeting.

\section{Results of the exploratory research study}

The results of the first research question regarding the individual perception of the digital transformation process are rather interesting. Undisputed by all three hierarchical levels is the fact that the main responsibility for the digital transformation in sales lies with the MD - and that the MD is also the major driver of the whole process. While the MDs agree that besides the MD also the IT department as well as marketing is driving the transformation process, SDs acknowledge primarily their customers as well as the IT department as additional drivers. The sales representatives, however, see the competitors as well as the marketing department as the second and third top drivers.

Most interesting of course is the driver not mentioned as a top driver: even though the topic of the research study was on "digital transformation in sales" and it was explicitly stated to all interviewees, none of the three groups sees the SD as a top driver in this process - not even the SDs themselves. It is therefore not surprising that transformation projects in sales often lack the necessary momentum (Figure 1).

Regarding the barriers, the two leadership positions, the MD as well as the SD, agreed fully on the two major barriers, i.e. 
Figure 1 Top three drivers and barriers of digital transformation in sales from the perspective of different hierarchical levels

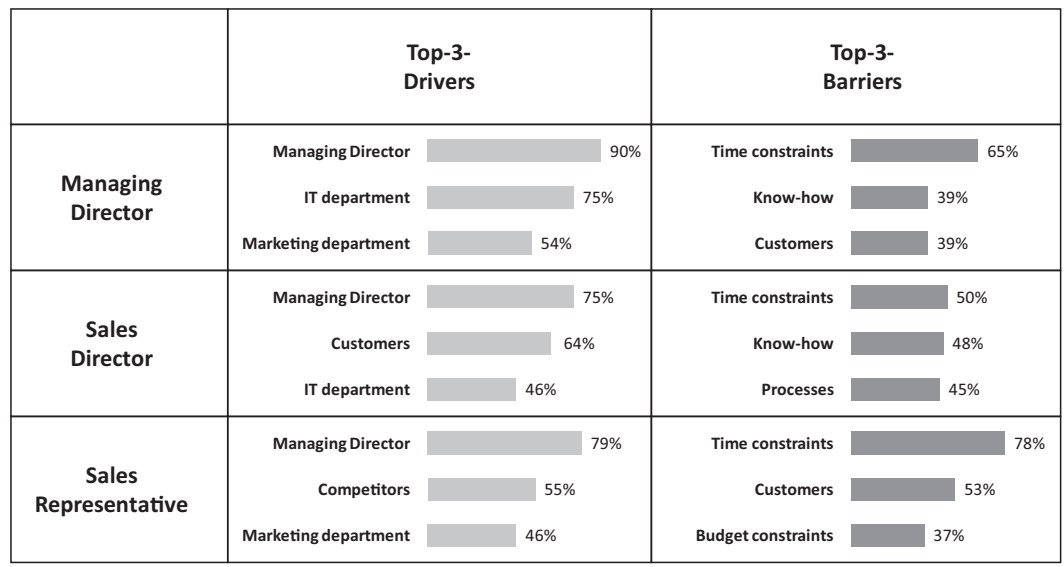

time constraints as well as a lack of necessary digitization knowhow. In this context, the third barrier of the SDs, who often see their sales processes not properly defined and designed to proceed with the digital transformation process is very important. Given these insights, the general hesitation of the SDs becomes thus more understandable. Interestingly, the SD thus raised similar concerns as other researchers (Buttle et al., 2006; Denner et al., 2018; Picot et al., 2008; Wright and Donaldson, 2002), who agree that a proper process design will be key for a successful digital transformation.

The sales representative provide a very interesting viewpoint as they agree with the other two regarding time constraints and with the $\mathrm{MD}$ regarding customers, who often do not seem to be sufficiently prepared - or who are using different systems. Instead, they see budget constraints as a major issue, but are fully convinced that the companies have the necessary know-how at hand for transforming sales properly. This misperception is fatal: it highlights the sales representatives' exaggerated trust in the companies' leadership teams (and thus puts a lot of burden on them), and also the sales representatives' lack of recognition of their own responsibility in the whole transformation process and of the necessity to acquire the missing digitization know-how themselves.
The results for the business-type related research questions are explained exemplary for each sales process step shown in Figure 2: as it becomes immediately evident in Figure 2, the sales process step "Market Analysis" has a much higher relevance in the product business $(20 \%)$ than in the project business $(5 \%)$ or the relational business $(5 \%)$. This result can be explained by the fact that the product business is characterized by focusing on a rather anonymous mass market and that the customer is hardly involved in the product development process. In contrast, the project business as well as the relational business are much more focused on individual customers - and the business transaction takes place in markets, which are rather small and manageable in size. As one SD of a tier-2 automobile supplier put it (following a relational business approach): "We got them [customers] all [...]! Why do we need to do an extra market analysis?"

The maximum digitization potential of this sales process step is assumed by companies in the product business at around $60 \%$ of the totally required activities of "Market Analysis." In the case of the project business, companies assume a proportion of around 35\% of all activities - and in the relational business even below that, at around $20 \%$. Asked for the current digitization degree of the sales process step, the results are

Figure 2 Sales process step "Market Analysis" across all three business types

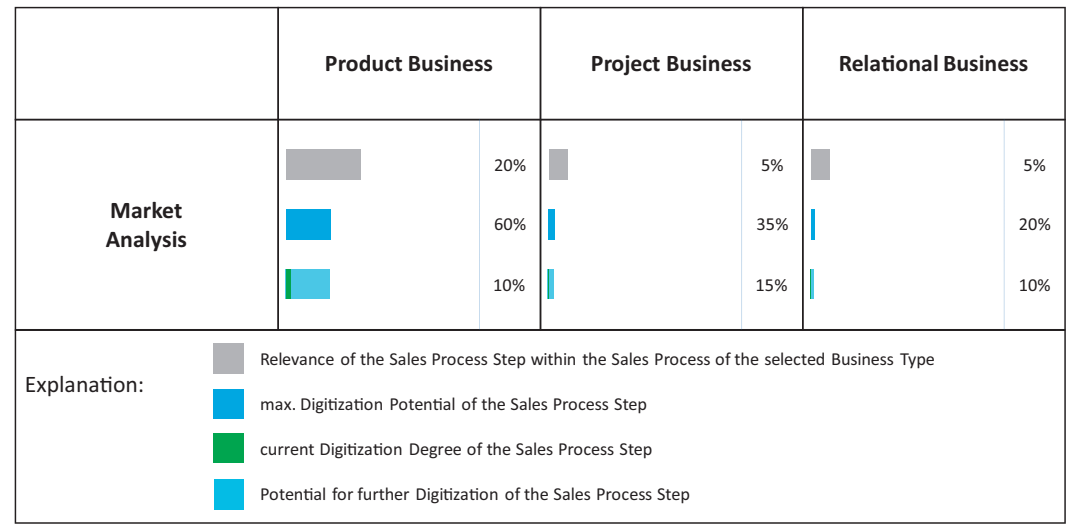


Figure 3 The complete sales process across all three business types

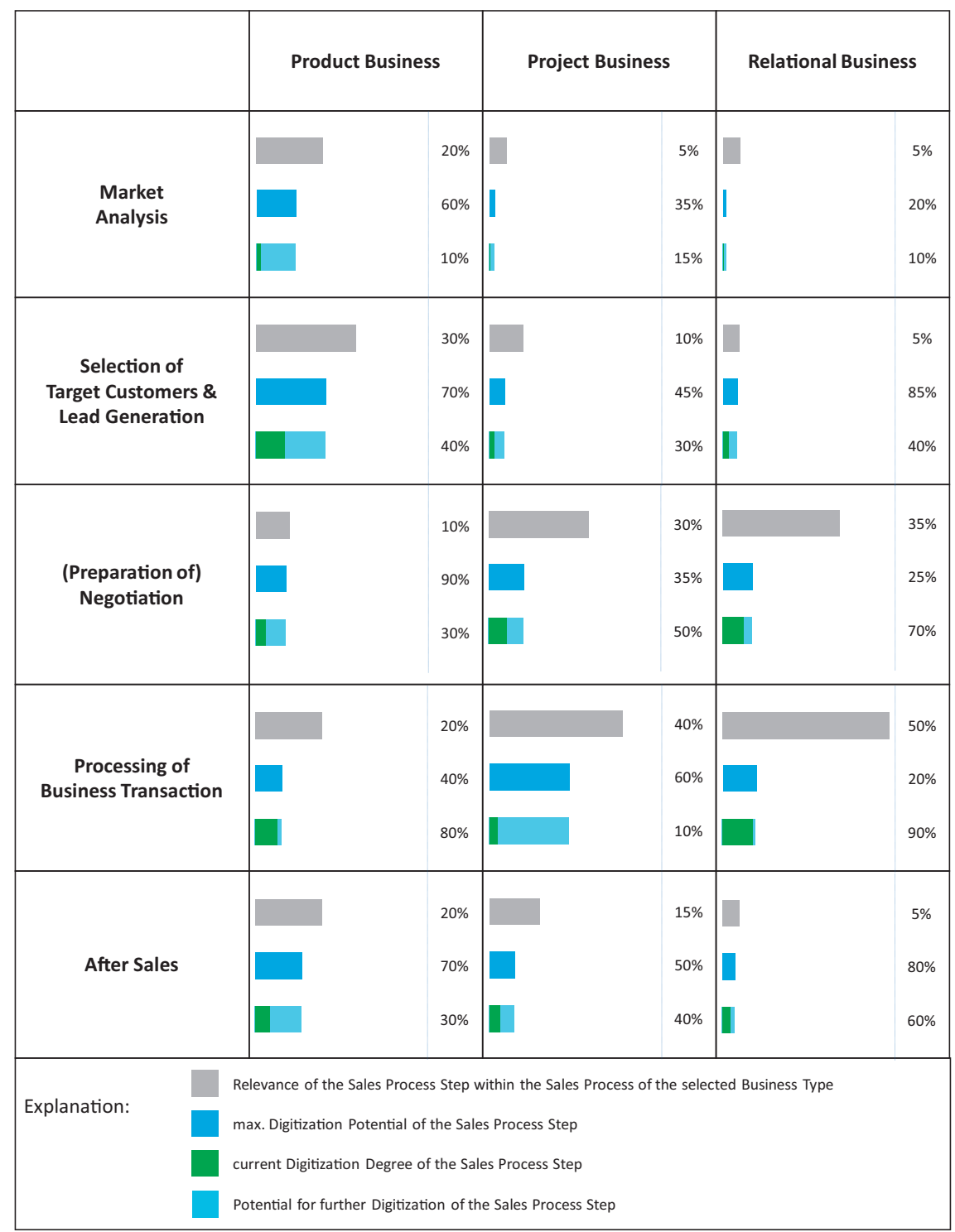

rather similar across all business types - varying between 10 and $15 \%$, i.e. much room for improvement is still given with respect to the digital transformation of this sales process step.

An assessment of the complete sales process as shown in Figure 3 confirms in a rather convincing way the substantial influence of the business type on the digital transformation in business-to-business sales. The relevance of the individual sales process steps as well as the maximal digitization degree deviate significantly between the three business types. While the selection of target customers and the generation of customer leads are of major importance for successful sales in the product business, the focus in the project business as well as the relational business lays on the processing of the business transaction. The different focuses can be explained because of the business types' characteristics: in the product business, the product already exists - and might already be in stock. An electronic order processing and a fast delivery process can easily be implemented; the more challenging task is the selection of attractive target customers and a proper lead generation. In contrast, the development and production of the service offering in the project business only starts after signing the contract as it includes e.g. power plants, buildings or consulting services. A similar situation occurs in the relational business, where companies only start their (joint) product development process after signing the contract.

The digitization degrees of the different sales process steps show considerable differences across the business types, too. The highest value of up to $90 \%$ can be found in the "Processing of Business Transaction" in the relational business type. Because of close supplier-customer relationships in this predominantly original equipment manufacturer business, companies are not only process-wise, but also (increasingly) IT-wise closely interlinked with each other - and allow a continuous stream and exchange of various data. In second place follows the product business also in the sales process step "Processing of Business Transaction" with around 80\%, which 
can be explained by the use of electronic market places or other e-commerce tools.

An important result of the interviews is the insight that in many sales process steps, the "manual" or "analogue" sales activities are still indispensable. Particularly the "(Preparation of) Negotiation" as well as "Processing of Business Transaction" in the relational business show low digitalization potential of just $25 \%$ or even $20 \%$, respectively. Also, the high digitization degree in the "Processing of Business Transaction" at around $80 \%$ in the product business should not cover up the fact that the process step's digitalization potential is just at around $40 \%$ - because of the (still) high degree of manual labor in many warehouses such as at Amazon.

Another essential outcome of the exploratory research was the fact that many companies are not only following one $(20 \%)$, but sometimes two (47\%) or even all three business types $(33 \%)$ at the same time. These situations are rather challenging for most small and medium-sized companies as they will try to follow one standardized digitalization approach regarding their IT systems, which will cause severe problems in their business processes - particularly with respect to their customers. As one interviewee put it: "Digitization ranges in this process step from 20-80\%." Asking for the reason behind this variance, he explained that since the implementation of a CRM system, the product business is covered $80 \%$ digitally, while for the project business, his colleagues have started to work again with paper and pencil as their old system was shut down after the CRM's implementation and the new CRM system does not fit at all to the existing workflow of the project business. Therefore, companies with two and three business types will have to accept the fact that each business type requires not only its own sales process design, but also its own IT templates (Figure 4).

The issue of capacity building (Schilke et al., 2018; Teece, 2007; Teece, 2014), i.e. building up know-how concerning "digital transformation in sales," played a major role in research question $R 8$. Most companies felt helpless regarding the aspect of "data," even though they are seen to be key in mastering the digital transformation (Helfat and Raubitschek, 2018). Neither do they really feel prepared to collect the correct data, nor do they know how to properly analyze and later use these data, results which are confirmed by similar research studies (Wright and Donaldson, 2002). In this context, the topic of MI, complementary to the more internally oriented business intelligence systems currently set up in most companies based on their finance and accounting data, came up very frequently, although none of the interviewed companies had any idea what a comprehensive MI should look like. Despite the awareness of the relevance of MI systems, companies are rather inactive regarding this topic, most probably because of insufficient knowledge of how to develop and implement it.
Another aspect raised in $R 8$ concerns digital tools and technologies. In this context, management boards feel like "being caught in the fog." Much is said about the great potential for business by using digital technologies [for an overview, see Singh et al. (2019) and Vial (2019)], but researchers are still surprisingly silent about when to use which digital tool and how it should be designed properly. Considering that hundreds of alternative digital tools exist, management's uncertainty in the context of business types is even more understandable.

Closely related to the new digital tools and technologies is the aspect of key performance indicators (KPIs). Interviewees repeatedly requested more information and ideas on KPIs, because new tools require new KPIs. Although a limited amount of new KPIs are suggested in the literature (Brynjolfsson and Kahin, 2002), hardly any of them have been introduced so far. Instead, managers still follow "oldschool" KPIs, which might not be applicable anymore like many years or even decades ago. Without suitable KPIs, however, it will be very difficult to manage a company properly in the digital era.

Given these uncertainties and misconceptions within the companies, it is in fact not surprising that most medium-sized companies are hesitant about their digital transformation in sales. A clearer direction for the transformation process and more specific ideas are required to move forward faster and with more confidence. Based on the literature review and on the empirical findings, the authors develop a conceptual transformation model, which will provide companies and its employees, on all hierarchical levels, proper guidance in the process of digital transformation in sales.

\section{Concept of the market-oriented transformation model}

For conceptualizing a market-oriented transformation model properly, it is important to understand that a company's ecosystem is deterministic for its value creation process - and thus also for digital transformation: while in the 1970s a more transactional perspective on business transactions dominated (Bagozzi, 1974; Kotler, 1972; Hunt, 1983), leading researchers took on a more relational perspective in the late 1980s/early 1990s (Bagozzi, 1994; Kotler, 1997; Morgan and Hunt, 1994). The change in research direction culminated in a rich stream of relationship marketing research (Day and Montgomery, 1999; Grönroos, 1994; Gummesson, 1994; Sheth and Parvatiyar, 1995). However, even the bilateral relationship perspective did not seem to suffice as companies became increasingly unable to create and deliver all the customer value by themselves, because of the growing complexity of their products. The research focus therefore shifted to value creation networks (Achrol, 1997;

Figure 4 Companies doing business in one or more business types

\begin{tabular}{|c|c|c|c|}
\hline \multirow{3}{*}{$\begin{array}{c}\text { Number of } \\
\text { Business Types }\end{array}$} & One & $20 \%$ & \multirow{3}{*}{$47 \%$} \\
\hline & Two & . & \\
\hline & Three & $33 \%$ & \\
\hline
\end{tabular}


Achrol and Kotler, 1999; de Man, 2004; Möller and Rajala, 2007). But again, it appears necessary to extend researchers' perspective as digital technologies span not only across company and network boundaries, but increasingly also across industries and affect various other stakeholders as well because of the growing economic interdependencies. Thus, the network perspective needs to be extended to the more comprehensive ecosystem perspective of value creation (Aarikka-Stenroos and Ritala, 2017) as neither company nor industry boundaries should constrain the process of (innovative) value creation for the customer in times of digital transformation (Picot et al., 2008). Even though the company's ecosystem consists of more than its customers, partners and competitors, the authors restricted their model to these three major stakeholders as they are constituent for the required market-oriented perspective (Day, 1994; Narver and Slater, 1990; Slater and Narver, 1995) within the company's value-creation process (Anderson and Narus, 1998; Slater, 1997; Woodruff, 1997) as well as to keep the market-oriented transformation model simple.

Whereas customers, partners and competitors represent the company's ecosystem and thus its external framework, the business model, the business type as well as the company's resources constitute its internal framework (Figure 5). Since Abell's (1980) approach of defining the business, the strategic importance of defining the relevant market and thus of the company's business model (Tikkanen et al., 2005) is undisputed in the marketing and sales literature. It has been explained in detail before that a company in business-tobusiness markets can thereby follow up to three different business types (Backhaus and Guenter, 1976; Backhaus and Muehlfeld, 2005) in delivering customer value (using many more sales channels). Its resource endowment determines the company's scale and scope as well as its management flexibility. For complexity reasons, the authors assume the business model, the business type as well as the company's resources as given. Even though we see enormous opportunities for new business models built upon evolving digital technologies as well as "Big Data" (Loebbecke and Picot, 2015), we assume that the transformation model starts out on the basis of the company's existing business and resources.

Derived from the insights of the interviews, "people," "processes" and "data" constitute the core of the marketoriented transformation model and have to be recognized as the main success factors of digital transformation as they can be directly influenced by and are under the direct control of the management team.

In accordance with the literature (Hess et al., 2016; Ross, 2019), the research study's findings back the key role of "people" in the context of "digital transformation in sales" as well as the need for additional capacity building in transformational times (Schilke et al., 2018; Teece, 2014). Thereby, the success factor "people" includes the company's management, its employees and the range of competencies across the company. Larger digital transformation projects will only succeed if the company's top management is actively involved and explicitly supports these projects (Ross, 2019), which was already recognized by the interviewed MDs. Understanding, accepting and taking on their leadership role becomes even more important as the employees' trust in their MDs' digitization capabilities and know-how is surprisingly high. At the same time it is reasonable: the whole transformation process is about changing existing workflows (fundamentally), eliminating traditional sales tasks or even implementing new business models to become a more marketoriented corporation. Therefore, employees need to have faith, that the transformation process will succeed and that in the long run they will also be part of the organization despite these fundamental changes; otherwise, the evolving job uncertainty would result in negative employee motivation. Another vital aspect in this context is the development of digital competencies at all levels [see also the discussion in Vial (2019)], especially dealing with data. More professional, market-oriented data management will be indispensable for the company's survival, which requires knowledge about searching, collecting and processing data as well as a stronger collaboration and teamwork within the sales team, but also across the company's various departments. Major adaptations

Figure 5 The market-oriented transformation model

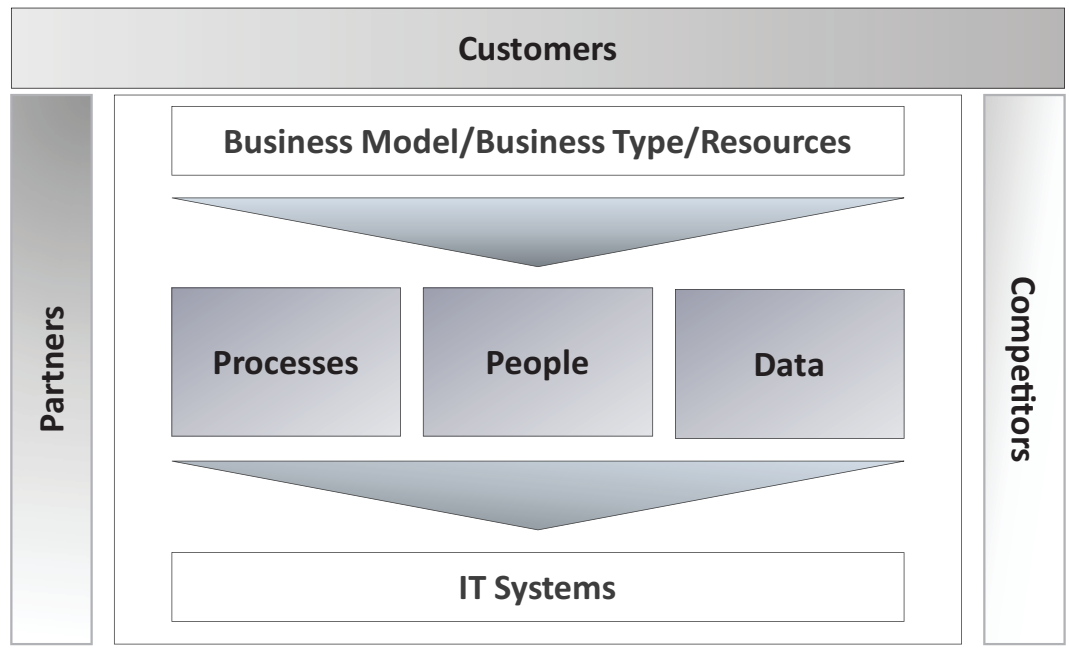


in the company's incentive structure will support the digital transformation - following Chandler's insight of "structure follows strategy" (Chandler, 1962).

The second success factor "processes" is regularly mentioned in the literature (Denner et al., 2018; Picot et al., 2008), but does not receive the attention it deserves (Buttle et al., 2006). In his research on the most relevant factors influencing a successful CRM implementation, Buttle (2004) identifies - besides people and technology - in particular "processes." In our interviews, particularly the SDs pointed the relevance of processes out and stressed the need to define them much more in detail, before digital transformation should take place at all. They seem to have understood that the management focus must shift from a currently onedimensional, department-oriented perspective toward a more customercentric, cross-departmental and - in selected cases - even a cross-company perspective (Storbacka et al., 2009). In future, thinking in terms of a corporate ecosystem has to become natural during the digital transformation process, while process mapping must primarily take place on the company level to avoid redundancies and inefficient processes (Steward et al., 2019). Otherwise, the following three risks will arise:

1 No proper review of whether the existing, analogue processes are contributing positively to the customers' value proposition. Subsequently, a non-value-adding process will be digitized at great expense, even though it is useless.

2 Fail to recognize that many processes must be completely re-designed. Because of the increasing use of digital technologies entirely new and so far, unknown opportunities can arise in the context of the humanmachine interface (HMI).

3 Process-relevant interfaces to other departments (e.g. marketing, customer service or accounting) are not considered, which will imply limited productivity gains in sales, and thus lower than expected customer benefits.

The third success factor "data" will culminate in a wellfunctioning data integration as well as a powerful and efficient database (Brynjolfsson and Hitt, 2000; Loebbecke and Picot, 2015). Eventually, the mapping and digitization of processes depends on data availability and data quality (Lemon and Verhoef, 2016). Nowadays, digital technologies provide potential access to a multitude of internal and external data sources, which offer the great opportunity of analyzing markets, customers and competitors more precisely than ever before (Tanner et al., 2005). Particularly customer requirements can be identified more systematically, and the company's product portfolio adapted accordingly. Such a sophisticated MI system supports especially high-expertise salespersons, who profit up to four times as much as average salespersons from such a $\mathrm{MI}$ system (Ko and Dennis, 2004). Consequently, more effort is required in building up sophisticated MI systems, which require in-depth knowledge about data generation, data analysis and data preparation within the company - capabilities that most of the interviewed companies still miss in the necessary quality and quantity.

In contrast to the more technology-driven literature on digital transformation [for an overview, see Vial (2019)] as well as to Buttle's (2004) key factors, we do not recognize technology itself as success factor, but more as a facilitator. The digital technologies do not deliver value by themselves, but can provide useful data or facilitate processes. Consequently, companies should only decide on the structure of their IT systems, after they are clear about the design of their three success factors. Unfortunately, in most companies, it is the other way around, but managers are afterwards taken by surprise that their digital transformation project failed (Davenport and Westerman, 2018) and that their people show strong resistance against the implied changes (Vial, 2019).

Even though the newly developed market-oriented transformation model takes on a rather inclusive perspective by describing a comprehensive external and internal framework as well as identifying three success factors for the digital transformation process, a dynamic component, characteristic for a transformation process, is so far missing. In accordance with Kane (2017), companies should view digital transformation not simply as a project, but as a continuous process. Thereby, companies should not simply pass time, but reach higher development stages because of digital transformation. As "digital transformation" implies primarily technological advancements supporting existing processes (Bharadwaj et al., 2013; Vial, 2019), six technological development stages can be distinguished in the context of digital transformation in sales:

1 stage 0: manual (data held in an analogue format in diverse places);

2 stage 1: digitization (availability of data in a digitized format);

3 stage 2: data integration (possibility to integrate available data in one data base);

4 stage 3: process automation (processing of available data in automized procedures);

5 stage 4: system integration (usage of available data across various IT systems); and

6 stage 5: AI (implementation and application of selflearning systems).

Stage 0 represents the classical situation in sales: customer and competitor data as well as internal data are available, but only in an analogue format as well as widespread across the company. The chances to ever bring these data together and analyze them systematically are nil because of prohibitive high costs. In stage 1, the available data are transformed from an analogue into a digital format, which people and departments do individually, but do not consider the difficulties of the diverse formats. The need to integrate data is recognized in stage 2, where all formats are standardized to allow for more systematic analyses by integrating them - at least virtually - into one database. Based on these synchronized data, process automation can take place at stage 3, i.e. simple, but repeating procedures can be taken over by digital technologies to automate these routines. Because companies operate various IT systems at the same time, it is of utmost importance that even these IT systems are enabled to exchange data and analytical results - if possible in real-time. Therefore, in stage 4, system integration takes place and will allow for the first time comprehensive data analyses across the company or even across company boundaries. The goal of most management boards is to achieve stage 5 by implementing AI. Although currently still in its infancy (Singh et al., 2019), self-learning systems will undoubtedly be the future and will take on a central role in sales. 
Assessed from a productivity perspective, digital transformation will only result in productivity gains from stage 3 onwards; stage 1 (digitization) and stage 2 (data integration) are just basic requirements to enable the IT infrastructure to provide the necessary content for in-depth analyses (Figure 6).

Productivity gains expected by researchers since the late 1970s (Brynjolfsson and Hitt, 1998, 2000) because of the increasing use of digital technologies were exaggerated as these development steps were neither considered in a systematic way nor across the whole company. Instead, most companies worked primarily on digitization and process automation, but were surprised about their limited productivity gains (Acemoglu et al., 2014; Davenport and Westerman, 2018). What they did not recognize is that relevant aspects such as data integration or system integration were not properly included in their digitization strategies - and thus, the expected productivity gains did not materialize.

Complementing the market-oriented transformation model with the dynamic perspective on digital transformation allows companies to better understand, how the internal success factors need to be designed in the respective development stage. As Figure 7 shows, the range of people's competencies, process designs or data requirements varies considerably with respect to the technological development of the company. However, the individual suggestions in the matrix of Figure 7 are still subject to further refinement and empirical testing.

Taking the results of the empirical research study as well as the poor outcome of many digital transformation processes (Acemoglu et al., 2014; Buttle et al., 2006; Davenport and Westerman, 2018) into account, the market-oriented transformation model provides a new perspective and a comprehensive explanation: for a company's successful digital transformation, it is of utmost importance that all three success factors are aligned with each other, even though this alignment will not happen by chance, but needs to be managed. In most cases, the company's recent competencies of these internal factors are differently developed. For example, a company can already work in the area of processes on an advanced "system integration," but its people are not sufficiently trained to use these systems, or the data are not available in the required quality and/or format. Within the process of digital transformation, it is however key that all categories are aligned with respect to their development stage. If this is not the case, digital transformation will only take place on the lowest development stage of all three success factors, which is often frustrating for management and employees. Investing further in success factors, which are already the most advanced ones, will therefore be a waste of resources (e.g. in the form of capital, time and/or management attention). Instead, the company's management should focus more on the less-developed factor(s) for catching up fast with the already more-developed factor(s).

\section{Management implications}

Implementing a proper digital transformation process poses a challenging management task, but is essential to increase a company's productivity. Various valuable management implications can be derived from the presented research results as well as the newly developed market-oriented transformation model:

- Understand digital transformation as an evolving process:

Digital transformation is not a project, but a continuous process. This requires a change of mindset in the companies' board of management as IT-related projects can no longer be "just" outsourced to external service providers or delegated to the IT department. Personal involvement of the top management as well as a continuous supply of sufficient human as well as financial resources will be required. Also, a company's digital transformation takes its time to pass through all five development stages. As one MD put it: "In digital transformation, there will be no short-cut."

- Create a company's “Digital Transformation Masterplan":

The management's responsibilities are growing in the digital era. Besides an increasing personal involvement in the transformation process, particularly MDs, but also team leaders need to provide better direction to their employees, who are putting a lot of faith in their proper guidance. Because of the expected fundamental changes within as well as across the company, an open communication of the company's digital strategies and operational measures in the form of a "Digital Transformation Masterplan" seem to be advisable to keep employees and team members mentally "on board" with the transformation process.

Figure 6 Technology-oriented development stage in digital transformation and the resulting productivity effects

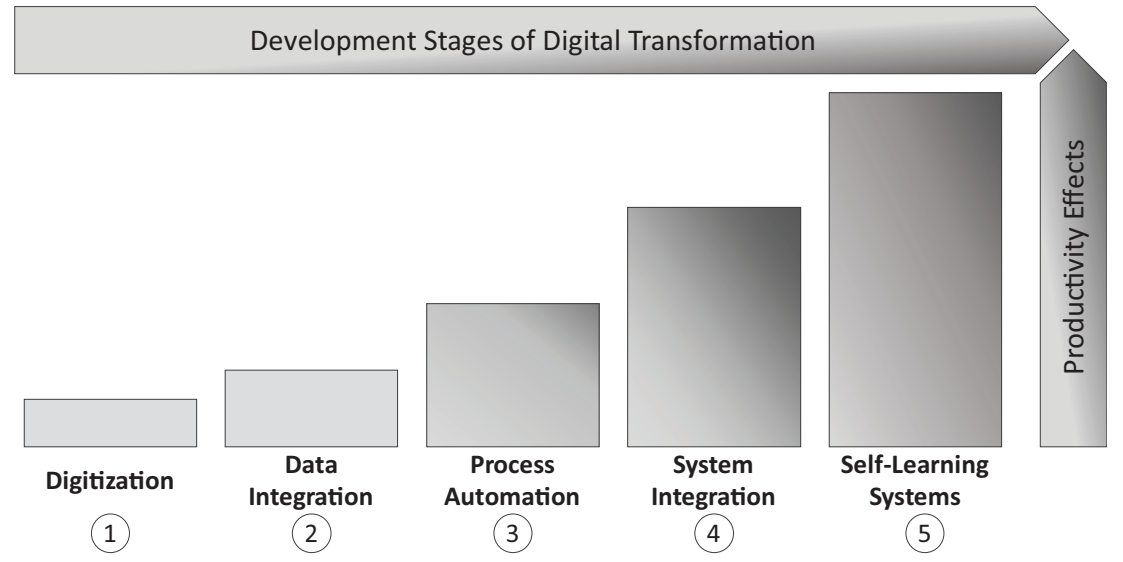


Figure 7 Market-oriented transformation matrix
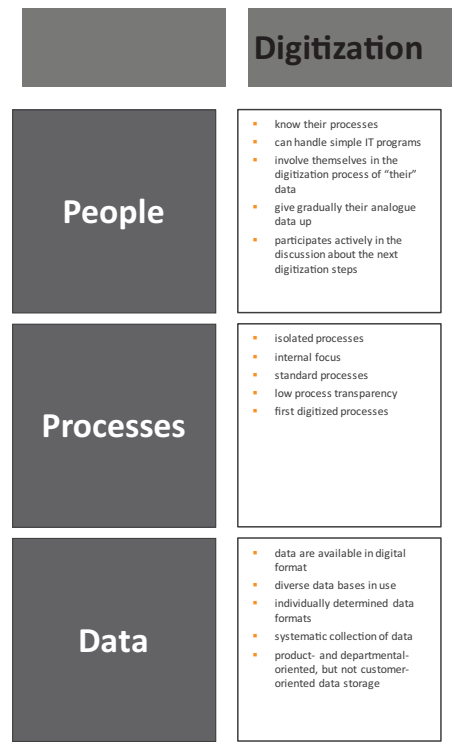
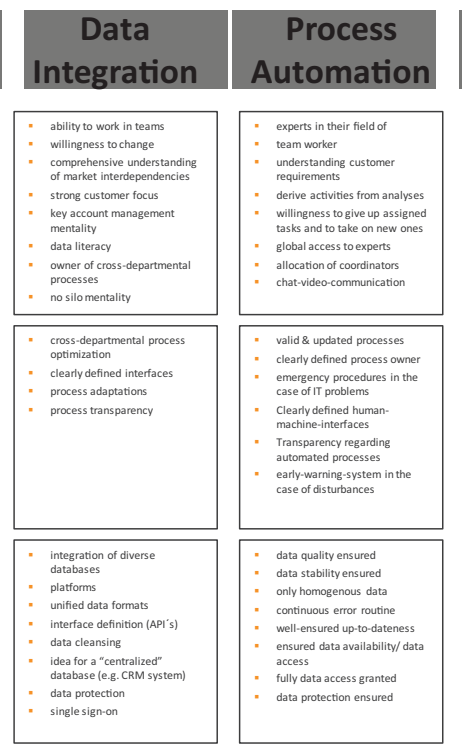
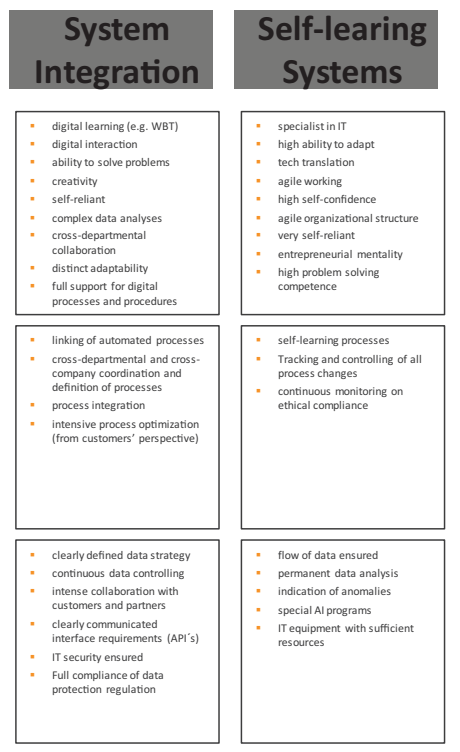

- Focus management attention on the configuration and development of the success factors:

During the development of our model, we focus primarily on the three success factors and set the external and internal framework constant, although the authors are aware that in business practice, all components of the model are in continuous flux. However, it is only an auxiliary structure to reduce management complexity in the first place and to facilitate companies in getting started with their digital transformation process.

Regarding the configuration of the three success factors, the management board has to ensure that they are designed in a market-oriented manner. As mentioned before, companies will have to transform themselves into market-oriented organizations - facilitated by sales and suitable digital technologies.

The management boards' main task will be to find out about the current development stage of each of the three success factors and harmonize them accordingly. Otherwise, resources are wasted. As soon as the success factors have reached similar development stages, managers have to advance them simultaneously.

- Re-design business and sales processes:

A specific focus should be put on the process design of companies. Besides the need to implement a more marketoriented approach, all business and sales processes need to be re-designed. Existing, but also upcoming digital technologies will require their conscious integration into current processes. Thus, the number of HMIs will significantly increase, but need to be purposefully handled by the management to ensure as well as increase the company's future competitiveness. This requires considerable adaptations of "people" and "processes" as well as a flexible IT structure.

- Develop new data capabilities and build up an integrated MI system:

A major issue for the interviewed companies was a lacking knowledge of handling data. Even though data and information have always been key to business success, digital technologies provide nowadays more data sources, easier access to these data sources as well as real-time data. By providing in-depth knowledge in data handling and turning them into meaningful information, a company can build up sophisticated as well as integrated MI systems. The more comprehensive the insights on the customers, competitors and markets are, the more likely are positive productivity effects - if MI systems are complemented with excellent salespersons (Ko and Dennis, 2004).

Digital transformation is currently keeping all companies busy as processes, products, business models as well as human behaviors are modified by digital technologies. Despite these changes, companies should not lose track of their most important objective, i.e. generating profit.

\section{Theoretical contribution, limitations and future research directions}

The newly developed market-oriented transformation model contributes to the already wide-ranging scientific discussion on digital transformation and sales management in various ways:

- Currently available definitions on "digital transformation" are mainly technology-oriented, which is inadequate in a management and sales context. Based on a rather comprehensive literature review, a management-oriented definition on "digital transformation" was derived, clarifying the unit of analysis, the transformation's scope, the means of the transformation as well as the expected outcome.

- The derived and conceptualized market-oriented transformation model captures, in a rather intuitive way, the external and internal framework of a company's digital transformation process as well as provides with respect to the various technological development stages rather specific recommendations regarding the management of the three success factors. While the relevance of people as 
well as the need to re-design processes in digital transformation are repeatedly discussed in the academic literature, data do not receive the necessary attention they deserve. Even though data's contribution to a successful digital transformation is essential, existing models concerned with digital transformation highlight instead "technology" as a major success factor (Buttle, 2004). However, in the course of this article, digital technologies have been qualified with regard to their relevance in the digital transformation process: although indispensable in the transformation process, digital technologies just take on the role of a "facilitator" or a "sales enabler" rather than providing value by themselves. The choice and design of the digital technology thus depend primarily on the company's framework and development stage of the success factors - not vice versa.

- Even though theoretically based on TCE, the idea of business types has hardly resonated in the academic literature outside Germany. This is surprising as the concept of business types is rather intriguing and provides important insights regarding the proper design and management of the sales process. Developed almost 50 years ago, its validity has been empirically proven over and over again as well as in the current research study. Because of its theoretical foundation, it meets the increasing requests for more theory-based research (Buttle et al., 2006). On top of this, it helps to understand and explain the varieties as well as the sometimes contradicting requirements on IT structure - not only within the same company, but even within the same strategic business unit. Thus, our research demonstrates that various approaches toward digital transformation are possible and that an increasing number of served business types will subsequently increase the complexity of a company's IT structure.

- For the first time, the sales process steps were assessed regarding their digitalization potential. Even though the assessment is based on self-reporting data, it provides some interesting insights: the results varied depending on the process steps as well as the business types, but also highlighted that some activities within the sales process might be better handled manually - today as well as in the future. Even though the proportion of automized activities will most probably increase with respect to technological progress, complex and customized business transactions will always require manual activities, because in these cases, it will be too costly to program new procedures or AI algorithms.

As the introduction of the market-oriented transformation model has made clear, the conceptual model itself cannot be considered mature and requires considerable further refinement. Although the 90 interviews were conducted individually and in one-to-one interview situations, it is important to acknowledge that only 30 different companies were included in the study, i.e. interdependency effects might be possible. As the study took exclusively place in Germany, the studies limitations are fully evident.

Besides broadening the empirical base, particularly more research has to be done in detailing the individual success factor as well as testing and applying the whole model. In this context, the comprehensive literature on dynamic capabilities (Helfat and Raubitschek, 2018; Schilke et al., 2018; Teece, 2007,2014 ) will provide interesting insights on the topic of capacity building - with respect to the transformation process in general as well as to the aspect of data handling. The challenge of re-designing processes and especially the organization and management of the newly created HMI require additional research attention. The increasing focus on mapping customer journeys and customer touchpoints (Lemon and Verhoef, 2016) is a promising step toward transforming companies into more market-oriented organizations. However, the identification of customer touchpoints might also help in identifying as well as creating valuable customer and market data. These data can support building up sophisticated MI systems and thus turn digital tools into smart "business/sales enablers." Also, the influence of the company's ecosystem (Bharadwaj et al., 2013; AarikkaStenroos and Ritala, 2017) and internal framework must be analyzed in further studies and how they impact the choice as well as the design of applied digital technologies. Another research focus should be on the development of new KPIs for the newly applied digital technologies. Without them, a proper management process aiming for productivity gains will be impossible.

\section{Conclusion}

"Digital transformation" can currently be considered as one of the most researched topics in sales management. Contributing to the growing number of scientific articles, the authors also conducted an exploratory research study on the current statusquo of "digital transformation in sales" in Germany. Based on the results of 90 expert interviews in 30 medium-sized companies, an evolving transformation model was inductively derived trying to capture the most relevant success factors in the context of digital transformation and trying to provide the companies' management boards proper direction for their transformation process.

As the results of the research study clearly indicate, digital transformation is a MD's topic, which requires their full management attention and support. In contrast to earlier days, digital transformation (in sales) cannot be considered a project anymore, but has to be recognized as a continuous transformation process keeping the company awake for the next decade(s).

Within this process, the company's employees will play a significant role, because they will be the ones who have to initiate and implement the transformation process. External help can only be a temporary solution, because if companies think about establishing and maintaining (new) competitive advantages, the development of internal (digital) competencies will be required. For really achieving substantial productivity gains, particularly the success factors "people," "process" and "data" require increasing management attention and need to be developed in a harmonized manner across the various technological development stages. The development and alignment of the three success factors will not be an easy management task, but essential for its company's success. 
Despite various limitations, the newly developed concept will contribute substantially to the scientific discussion of digital transformation in sales as it provides for the first time a comprehensive management model giving proper direction in the context of "digital transformation in sales" for managers and employees alike.

\section{References}

Aarikka-Stenroos, L. and Ritala, P. (2017), "Network management in the era of ecosystems: systematic review and management framework", Industrial Marketing Management, Vol. 67, pp. 23-36.

Abell, D.F. (1980), Defining the Business: The Starting Point of Strategic Planning, Prentice Hall, Englewood Cliffs, NJ.

Acemoglu, D., Autor, D., Dorn, D., Hanson, G. and Price, B. (2014), "Return of the Solow paradox? IT, productivity, and employment in US manufacturing", American Economic Review, Vol. 104 No. 5, pp. 394-399.

Achrol, R.S. (1997), "Changes in the theory of interorganizational relations in marketing: toward a network paradigm", Fournal of the Academy of Marketing Science, Vol. 25 No. 1, pp. 56-71.

Achrol, R.S. and Kotler, P. (1999), "Marketing in the network economy", fournal of Marketing, Vol. 63 No. 4, pp. 146-163.

Agarwal, R., Guodong, G., DesRoches, C. and Jha, A.K. (2010), "The digital transformation of healthcare: current status and the road ahead", Information Systems Research, Vol. 21 No. 4, pp. 796-809.

Ancillai, C., Terho, H., Cardinali, S. and Pascucci, F. (2019), "Advancing social media driven sales research: establishing conceptual foundations for B-to-B social selling", Industrial Marketing Management, Vol. 82, pp. 293-308.

Anderson, J.C. and Narus, J.A. (1998), "Business marketing: understand what customers value", Harvard Business Review, November-December 1998, pp. 5-15.

Anderson, J.C., Narus, J.A. and Narayandas, D. (2008), "Business market management: understanding", Creating, and Delivering Value, 3rd ed., Pearson, Upper Saddle River, NJ.

Backhaus, K. and Guenter, B. (1976), "A phase-differentiated interaction approach to industrial marketing decisions", Industrial Marketing Management, Vol. 5 No. 5, pp. 255-270.

Backhaus, K. and Muehlfeld, K. (2005), "Strategy dynamics in industrial marketing: a business types perspective", Management Decision, Vol. 43 No. 1, pp. 38-55.

Bagozzi, R.P. (1974), "Marketing as an organized behavioral system of exchange: a comprehensive and analytic structure for interpreting behavior in marketing relationships", fournal of Marketing, Vol. 38 No. 4, pp. 77-81.

Bagozzi, R.P. (1994), "Interactions in small groups: the social relations model", Sheth, J.N. and Parvatiyar, A. (Eds), Relationship Marketing: Theory, Methods and Applications, Center of Relationship Marketing, Emory University, Atlanta, GA.

Bagozzi, R.P., Yi, Y. and Phillips, L.W. (1991), “Assessing construct validity in organizational research", Administrative Science Quarterly, Vol. 36 No. 3, pp. 421-458.

Bharadwaj, A., El Sawy, O.A., Pavlou, P.A. and Venkatraman, N. (2013), "Digital business strategy: toward a next generation of insights", MIS Quarterly, Vol. 37 No. 2, pp. 471-482.

Bohlig, A. and Care, J. (1975), Mastering Technical Sales: The Sales Engineer's Handbook, 3rd ed., Artech House Publishers, London.

Bronfenbrenner, U. (1979), The Ecology of Human Development, Harvard University Press, Cambridge, MA.

Brynjolfsson, E. and Hitt, L. (1998), "Beyond the productivity paradox", Communications of the Acm, Vol. 41 No. 8, pp. 49-55.

Brynjolfsson, E. and Hitt, L. (2000), "Beyond computation: information technology, organizational transformation and business performance", Fournal of Economic Perspectives, Vol. 14 No. 4, pp. 23-48.

Brynjolfsson, E. and Kahin, B. (2002), Understanding the Digital Economy: Data, Tools, and Research, The MIT Press, Cambridge, MA.

Buttle, F. (2004), Customer Relationship Management: Concepts and Tools, Elsevier, Oxford.

Buttle, F., Ang, L. and Iriana, R. (2006), "Sales force automation: review, critique, research agenda", International Fournal of Management Reviews, Vol. 8 No. 4, pp. 213-231.

Cascio, R., Mariadoss, B.J. and Mouri, N. (2010), "The impact of management commitment alignment on salespersons' adoption of sales force automation technologies: an empirical investigation", Industrial Marketing Management, Vol. 39 No. 7, pp. 1088-1096.

Chandler, A.D. (1962), Strategy and Structure: Chapters in the History of the American Industrial Enterprise, Beard Group Inc, Frederick, MD.

Chierici, R., Mazzucchelli, A., Garcia-Perez, A. and Vrontis, D. (2019), "Transforming big data into knowledge: the role of knowledge management practice", Management Decision, Vol. 57 No. 8, pp. 1902-1922.

Choa, S.D. and Chang, D.R. (2008), "Salesperson's innovation resistance and job satisfaction in intraorganizational diffusion of sales force automation technologies: the case of South Korea", Industrial Marketing Management, Vol. 37 No. 7, pp. 841-847.

Chowdhury, S., Haftor, D. and Pashkevich, N. (2018), "Smart Product-Service systems (smart PSS) in industry firms: a literature review", Procedia CIRP 73 of 10th CIRP Conference on Industrial Product-Service Systems (IPS2), Linköping, Sweden, 29-31 May 2018, pp. 26-31.

Churchill, G.A. (1979), "A paradigm for developing better measures of marketing constructs", fournal of Marketing Research, Vol. 16 No. 1, pp. 64-73.

Cuevas, J.M., Donaldson, B. and Lemmens, R. (2015), Sales Management: strategy, Process and Practice, 4th ed., Red Globe Press, London.

Davenport, T.H. and Westerman, G. (2018), "Why so many high-profile digital transformations fail", Harvard Business Review, Cambridge.

Day, G.S. (1994), "The capabilities of market-driven organizations", Fournal of Marketing, Vol. 58 No. 4, pp. 37-52.

Day, G.S. and Montgomery, D.B. (1999), "Charting new directions for marketing", fournal of Marketing, Vol. 63 No. 4, pp. 3-13. 
de Man, A.P. (2004), The Network Economy, Edward Elgar Publishing, Cheltenham.

Denner, M.-S., Püschel, L.C. and Röglinger, M. (2018), "How to exploit the digitalization potential of business processes", Business E Information Systems Engineering, Vol. 60 No. 4, pp. 331-349.

Elia, G., Polimeno, G., Solazzo, G. and Passiante, G. (2020), "A multi-dimension framework for value creation through big data", Industrial Marketing Management, Vol. 90, Article in Press.

Ginzberg, M.J. (1981), "Early diagnosis of MIS implementation failure: promising results and unanswered questions", Management Science, Vol. 27 No. 4, pp. 459-478.

Gordon, R.J. (2016), Rise and Fall of American Growth - The U.S. Standard of Living since the Civil War, Princeton University Press, Princeton, NJ.

Grönroos, C. (1994), "Quo vadis, marketing? Toward a relationship marketing paradigm", Fournal of Marketing Management, Vol. 10 No. 5, pp. 347-360.

Guenzi, P. and Geiger, S. (2011), Sales Management: A Multinational Perspective, Red Globe Press, London.

Gummesson, E. (1994), "Making relationship marketing operational", International fournal of Service Industry Management, Vol. 5 No. 5, pp. 5-20.

Hajlia, N., Tajvidi, M., Gbadamosi, A. and Nadeem, W. (2020), "Understanding market agility for new product success with big data analytics", Industrial Marketing Management, Vol. 86, Article in Press.

Hallikainen, H., Savimäki, E. and Laukkanen, T. (2020), "Fostering B2B sales with customer big data analytics", Industrial Marketing Management, Vol. 86, Article in press.

Helfat, C.E. and Raubitschek, R.S. (2018), "Dynamic and integrative capabilities for profiting from innovation in digital platform-based ecosystems", Research Policy, Vol. 47 No. 8, pp. 1391-1399.

Hess, T., Matt, S., Benlian, A. and Wiesböck, F. (2016), "Options for formulating a digital transformation strategy", MIS Quarterly Executive, Vol. 15 No. 2, pp. 123-139.

Hill, N.C. and Swenson, M.J. (1994), "Sales technology applications: the impact of electronic data interchange on the sales function", Fournal of Personal Selling \& Sales Management, Vol. 14 No. 3, pp. 79-87.

Hirsch-Kreinsen, H. (2016), "Digitization of industrial work: development paths and prospects", fournal for Labour Market Research, Vol. 49 No. 1, pp. 1-14.

Homburg, C., Klarmann, M., Reimann, M. and Schilke, O. (2012), "What drives key informant accuracy?", fournal of Marketing Research, Vol. 49 No. 4, pp. 594-608.

Honeycutt, E.D. (2005), "Technology improves sales performance - doesn't it? An introduction to the special issue on selling and sales technology", Industrial Marketing Management, Vol. 34 No. 4, pp. 301-304.

Honeycutt, E.D. (2002), "Sales management in the new millennium: an introduction", Industrial Marketing Management, Vol. 31 No. 7, pp. 555-558.

Hunt, S.D. (1983), "General theories and the fundamental explananda of marketing”, fournal of Marketing, Vol. 47 No. 4, pp. 9-17.
Hunt, S.D. and Duhan, D.F. (2002), "Competition in the third millennium: efficiency or effectiveness?", fournal of Business Research, Vol. 55 No. 2, pp. 97-102.

Iansiti, M. and Lakhani, K.R. (2014), "Digital ubiquity: how connections, sensors, and data are revolutionizing business", Harvard Business Review, Vol. 92 No. 11.

Ingram, T.N., LaForge, R.W., Schwepker, C.H. and Williams, M.R. (2015), Sales Management: Analysis and Decision Making, 8th ed., Routledge, Abingdon.

Johnston, M.W. and Marshall, G.W. (2013), Sales Force Management, 11 th ed., Routledge, Abingdon.

Kane, G.C. (2017), "Digital maturity, not digital transformation", MIT Sloan Management Review, available at: http://sloanreview.mit.edu/article/digital-maturity-notdigitaltransformation/, (published: 4th April 2017).

Ko, D.-G. and Dennis, A.R. (2004), "Sales force automation and sales performance: do experience and expertise matter?", fournal of Personal Selling \& Sales Management, pp. 311-322.

Kotler, P. (1972), “A generic concept of marketing”, fournal of Marketing, Vol. 36 No. 2, pp. 46-54.

Kotler, P. (1997), Marketing Management - Analysis, Planning, Implementation and Control, 9th ed., Prentice Hall, Englewood Cliffs, N.J.

Kumar, V. and Reinartz, W. (2016), "Creating enduring customer value", fournal of Marketing, Vol. 80 No. 6, pp. 36-68.

Kumar, B., Sharma, A., Vatavwala, S. and Kumar, C. (2020), "Digital mediation in business-to-business marketing: a bibliometric analysis", Industrial Marketing Management, Vol. 85, Article in Press.

Lamberton, C. and Stephen, A.T. (2016), "A thematic exploration of digital, social media, and mobile marketing: research evolution from 2000 to 2015 and an agenda for future inquiry", fournal of Marketing, Vol. 80 No. 6, pp. 146-172.

Lemon, K.N. and Verhoef, P.C. (2016), "Understanding customer experience throughout the customer journey", Fournal of Marketing, Vol. 80 No. 6, pp. 69-96.

Loebbecke, C. and Picot, A. (2015), "Reflections on societal and business model transformation arising from digitization and big data analytics: a research agenda", The fournal of Strategic Information Systems, Vol. 24 No. 3, pp. 149-157.

Majchrzak, A., Markus, M.L. and Wareham, J. (2016), "Designing for digital transformation: lessons for information systems research from the study of ICT and societal challenges", MIS Quarterly, Vol. 40 No. 2, pp. 267-277.

Matt, C., Hess, T. and Benlian, A. (2015), "Digital transformation strategies", Business \& Information Systems Engineering, Vol. 57 No. 5, pp. 339-343.

Möller, K. and Rajala, A. (2007), "Rise of strategic nets - new modes of value creation", Industrial Marketing Management, Vol. 36 No. 7, pp. 895-908.

Morgan, R.M. and Hunt, S.D. (1994), "The commitmenttrust theory of relationship marketing", fournal of Marketing, Vol. 58 No. 3, pp. 20-38.

Narver, J.C. and Slater, S.F. (1990), "The effect of a market orientation on business profitability", fournal of Marketing, Vol. 54 No. 4, pp. 20-35. 
Nunan, D., Sibai, O., Schivinski, B. and Christodoulides, G. (2018), "Reflections on 'social media: influencing customer satisfaction in B2B sales' and a research agenda", Industrial Marketing Management, Vol. 75, pp. 31-36.

Obal, M. and Lancioni, R.A. (2013), "Maximizing buyersupplier relationships in the digital era: concept and research agenda", Industrial Marketing Management, Vol. 42 No. 6, pp. 851-854.

Pascucci, F., Ancillai, C. and Cardinali, S. (2018), "Exploring antecedents of social media usage in B2B: a systematic review", Management Research Review, Vol. 41 No. 6, pp. 629-656.

Picot, A., Reichwald, R. and Wigand, R. (2008), Information, Organization and Management, Springer, Berlin-Heidelberg.

Rindfleisch, A., Malter, A.J., Ganesan, S. and Moorman, C. (2008), "Cross-sectional versus longitudinal survey research: concepts, findings, and guidelines", fournal of Marketing Research, Vol. 45 No. 3, pp. 261-279.

Ritter, T. and Pedersen, C.L. (2020), "Digitization capability and the digitalization of business models in business-tobusiness firms: past, present, and future", Industrial Marketing Management, Vol. 86, pp. 180-190.

Ross, J. (2019), "Don't confuse digital with digitization”, in: who wins in a digital world?: Strategies to make your organization fit for the future", MIT Sloan Management Review, pp. 3-7.

Saniee, I., Kamat, S., Prakash, S. and Weldon, M. (2017), "Will productivity growth return in the new digital era? An analysis of the potential impact on productivity of the fourth industrial revolution", Bell Labs Technical fournal, Vol. 22, pp. 1-18.

Schilke, O., Hu, S. and Helfat, C.E. (2018), "Quo vadis, dynamic capabilities? A content-analytic review of the current state of knowledge and recommendations for future research", Academy of Management Annals, Vol. 12 No. 1, pp. 390-439.

Shapiro, C. and Varian, H. (1999), Information Rules: A Strategic Guide to the Network Economy, Harvard Business School Press, Boston, MA.

Sheth, J.N. and Parvatiyar, A. (1995), "The evolution of relationship marketing", International Business Review, Vol. 4 No. 4, pp. 397-418.

Singh, J., Flaherty, K., Sohi, R.S., Deeter-Schmelz, D., Habel, J., Le Meunier-FitzHugh, K., Malshe, A., Mullins, R. and Onyemah, V. (2019), "Sales profession and professionals in the age of digitization and artificial intelligence technologies: concepts, priorities, and questions", Fournal of Personal Selling \& Sales Management, Vol. 39 No. 1, pp. 1-21.

Slater, S.F. (1997), "Developing a customer value-based theory of marketing", fournal of the Academy of Marketing Science, Vol. 25 No. 2, pp. 162-167.

Slater, S.F. and Narver, J.C. (1995), "Market orientation and the learning orientation", fournal of Marketing, Vol. 59 No. 3, pp. 63-74.

Solow, R. (1987), "We'd better watch out", New York Times Book Review, The New York Times, published: 12th fuly 1987.

Speier, C. and Venkatesh, V. (2002), "The hidden minefields in the adoption of sales force automation technologies", Fournal of Marketing, Vol. 66 No. 3, pp. 98-111.
Srivastava, R.K., Shervani, T.A. and Fahey, L. (1999), "Marketing, business processes, and shareholder value: an organizationally embedded view of marketing activities and the discipline of marketing", fournal of Marketing, Vol. 63 No. 4, pp. 168-179.

Steel, M., Dubelaar, C. and Ewing, M.T. (2013), "Developing customized CRM projects: the role of industry norms, organizational context and customer expectations on CRM implementation", Industrial Marketing Management, Vol. 42 No. 8, pp. 1328-1344.

Stein, A., Smith, M.F. and Lancioni, R.A. (2013), "The development and diffusion of customer relationship management (CRM) intelligence in business-to-business environments", Industrial Marketing Management, Vol. 42 No. 6, pp. 855-861.

Steward, M.D., Narus, J.A., Roehm, M.L. and Ritz, W. (2019), "From transactions to journeys and beyond: the evolution of B2B buying process modeling", Industrial Marketing Management, Vol. 83, pp. 288-300.

Storbacka, K., Ryals, L., Davies, I. and Nenonen, S. (2009), "The changing role of sales: viewing sales as a strategic, cross-functional process", European Fournal of Marketing, Vol. 43 Nos 7/8, pp. 890-906.

Tabrizi, B., Lam, E., Girard, K. and Irvin, V. (2019), "Digital transformation is not about technology", Harvard Business Review, Issue March 2019, Cambridge.

Tanner, J.F., Ahearne, M., Leigh, T.W., Mason, C.H. and Moncrief, W.C. (2005), "CRM in sales-intensive organizations: a review, and future directions", fournal of Personal Selling \& Sales Management, Vol. 25 No. 2, pp. 169-180.

Teece, D.J. (2007), "Explicating dynamic capabilities: the nature and microfoundations of (sustainable) enterprise performance", Strategic Management fournal, Vol. 28 No. 13, pp. 1319-1350.

Teece, D.J. (2014), "The foundations of enterprise performance: dynamic and ordinary capabilities in an (economic) theory of firms", Academy of Management Perspectives, Vol. 28 No. 4, pp. 328-352.

Terho, H., Haas, A., Eggert, A. and Ulaga, W. (2012), "It's almost like taking the sales out of selling' - towards a conceptualization of value-based selling in business markets", Industrial Marketing Management, Vol. 41 No. 1, pp. 174-185.

Tikkanen, H., Lamberg, J.-A., Parvinen, P. and Kallunki, J.-P. (2005), "Managerial cognition, action and the business model of the firm", Management Decision, Vol. 43 No. 6, pp. 789-809.

Ulaga, W. and Eggert, A. (2006), "Value-based differentiation in business relationships: gaining and sustaining key supplier status", Fournal of Marketing, Vol. 70 No. 1, pp. 119-136.

Van Bruggen, G.H., Lilien, G.L. and Kacker, M. (2002), "Informants in organizational marketing research: why use multiple informants and how to aggregate responses", Fournal of Marketing Research, Vol. 39 No. 4, pp. 469-478.

Vial, G. (2019), "Understanding digital transformation: a review and a research agenda", The fournal of Strategic Information Systems, Vol. 28 No. 2, pp. 118-144. 
Wang, W.Y.C. and Wang, Y. (2020), "Analytics in the era of big data: the digital transformations and value creation in industrial marketing", Industrial Marketing Management, Article in Press.

Wang, Y., Rod, M., Ji, S. and Deng, Q. (2017), "Social media capability in B2B marketing: toward a definition and a research model”, fournal of Business E Industrial Marketing, Vol. 32 No. 8, pp. 1125-1135.

Westerman, G., Calméjane, C., Bonnet, D., Ferraris, P. and McAfee, A. (2011), Digital Transformation: A Roadmap for Billion-Dollar Organizations, MIT Center for Digital Business and Capgemini Consulting, Cambridge.

Williamson, O.E. (1975), "Markets and hierarchies - analysis and antitrust implications", London 1975.

Wirtz, J. and Ehret, M. (2017), "Capturing value in the service economy", Fournal of Service Management Research, Vol. 1 No. 1, pp. 22-38.

Wolfswinkel, J.F., Furtmueller, E. and Wilderom, C.P.M. (2013), "Using grounded theory as a method for rigorously reviewing literature", European fournal of Information Systems, Vol. 22 No. 1, pp. 1-11.

Woodruff, R.W. (1997), "Customer value: the next source for competitive advantage", Fournal of the Academy of Marketing Science, Vol. 25 No. 2, pp. 139-153.

Wotruba, T.R. (1981), Sales Management: Concepts, Practice and Cases, Goodyear Publishing Co.

Wright, G. and Donaldson, B. (2002), "Sales information systems in the UK financial services industry: an analysis of sophistication of use and perceived barriers to adoption", International fournal of Information Management, Vol. 22 No. 6, pp. 405-419.

Zuboff, S. (1988), In the Age of the Smart Machine: The Future of Work and Power, Basic Books, New York, NY.

\section{Corresponding author}

Stefan Wengler can be contacted at: stefan.wengler@hofuniversity.de 